\title{
Public Indebtedness in Punjab State of India: A Critical Review
}

\author{
Harvinder Kaur ${ }^{1 *}$ and Navdeep Kaur ${ }^{2}$ \\ ${ }^{1}$ Department of Economics, Distance Education, Punjabi University, Patiala, Punjab, India \\ ${ }^{2}$ Department of Economics, Punjabi University, Patiala, Punjab, India \\ *Corresponding author: harvinder1964@gmail.com
}

\begin{abstract}
A neoteric phenomena which has put the Indian economy under unbearable pressure is ballooning borrowings because of unceasing expenditure by the governments. In India, rising debt to GDP ratio has accentuated the problem of outpacing revenue expenditure which led to the implementation of FRBM Act, 2003 and after that indebtedness among states has declined. So, this paper focuses on the analysis of public indebtedness of non special category states of India and to access the level of indebtedness, debt to GDP ratio is taken. The state that has emerged as one of the weakest in tackling with the situation of growing indebtedness is Punjab over the period of 2000-2017 along with West Bengal because of rise in revenue expenditure especially the non-development component, stagnant growth in state's own tax revenue and sliding non-tax revenues. States like Odisha, Chhattisgarh, Andhra Pradesh, Madhya Pradesh and Bihar have low Debt to GSDP ratio and are spending more on developmental activities whereas the Punjab state is spending very less amount on developmental activities and more interest payments which can lead to the further deteriorate the financial health of the state.
\end{abstract}

Keywords: Public debt, development expenditure, interest payments

Resorting to public borrowings has become a compulsion now-a-days for most of the nations of the world. Earlier the governments had been using this instrument for war financing, self liquidating projects and to fill the deliberately created revenue gap. But now the condition is such that governments borrow to meet the revenue account needs of an economy. No doubt they are freely resorting to these instruments but in a broader macroeconomic context, it is always recommended that the level and rate of growth of public debt should be fundamentally sustainable. The reason behind this is a large increase in public debt and interest payments year after year can adversely affect the growth process by diverting resources from productive purposes to repayment of debt and interest payments. Since classical time period, the views on its positive or negative impact have always remained controversial issue. For example, Classical economists considered the financing of public spending via borrowings detrimental to a country's wealth generating capacity (Tsoulfids,
2007). Since, they had a pessimistic approach towards the public debt. However, the opinion turned in the favour of public debt after the depression of 1930s as Keynesian theory played an important role in this respect. In his opinion, more public expenditure via borrowings by the government would help to create effective demand in the period of depression in an economy (Bilan 2016). However, Monetarist economists denied the Keynesian view and neglected the positive effect of borrowings or deficit financing aimed at stabilising the economy. Further, Modern economists like Prof. A.H. Hansen favoured public debt and considered it as an essential means of increasing employment and an important instrument of modern economic policy of nations. Whatever the theoretical base regarding public debt has remained, now due to ever growing governmental scale of activities and expenses, countries don't have a choice to follow the critics' version that considered it a curse and argued that government debt has repercussions on fiscal and debt sustainability. So, most of the countries have 
been incurring new debt maybe due to compulsion or considering the proponents version of arguing for its positive impacts on growth. As even the critics considered direct public works suitable for loan financing but recently the instruments of borrowings has become an essential part of the development of an economy when it lacks financial resources. Despite addiction to public debt,in recent years, mounting public debt has become a burning issue for both developed and developing economies because it can drag down the growth if not used in an efficient and prudent manner. The picture of public debt in the developed economies looks more worrisome as Japan being the most indebted nation in the world followed by Germany. According to the World Bank's Report- International Debt Statistics 2017, Japan's debt to GDP ratio is more than 200 per cent due to soaring spending on social services for ageing people accompanied with slow GDP growth. The pressure will increase more in the developed economies in near future because of expanding health care and pension spending and large primary gaps (Carlo 2010). Among developing economies likeBrazil, Mauritius, Pakistan and Sri Lanka have the highest ratio of Debt to GDP (International debt statistics 2017). India is also not an exception as among the emerging economies, its public debt is highest (Joumard, et al. 2017). Since, India is a federal nation and states depend upon the centre for various types of support. To get such support, one broad criterion is categorising states into special and non special category states. Since state of Punjab falls in the non special category states. So, this paper focuses on the non special category states of India and the study covers the period of 2000-2015. The outstanding liabilities of Punjab state have been continuously increasing and it is almost at the risk of falling into a debt trap. The main objectives of the study are:

(a) To study whether the implementation of FRBM Act has lead to decline in the debt of centre and state government.

(b) To analyse the fiscal situation of non-special category states.

(c) To study the extent to which the states are disbursing on development areas or on interest payments and debt servicing.

(d) To study the public debt scenario of Punjab.

\section{Public Debt scenario in India}

Reliance on public debt in India is not a recent phenomenon. The need started since independence as huge financial resources were required for compelling need of economic development at that time. On account of heavy expenditure on defence (because of external conflicts), basic industry and rural development, the problem of fiscal imbalances originated. But huge dependence on borrowings since 1980s (largely attributed to unchecked growth of non-plan revenue expenditure particularly on interest payments and subsidies) eventually lead to the financial crisis of 1991. As a result, some measures were taken to correct fiscal imbalances and to ensure economic growth and stability like government imposed 5 per cent cut on the expenditure and introduced proposals for raising revenue in the budget of 1991-92. The situation improved to some extent for some time. Nevertheless after 1997, the state again started deteriorating because of reduction in tax rates, hike in wages and salaries as per recommendations of $5^{\text {th }}$ Pay Commission and increasing non-development expenditure. Further, the contemplation that the implementation of the recommendations of Seventh Pay Commission, increasing oil prices and farm loan waivers can make the fiscal situation vulnerable and has made India more cautious. India's internal debt to GDP ratio of the centre government was 47.52 per cent and external debt to GDP ratio constituted a small proportion of 2.78 per cent in 2016-17 which means low currency risk to GoI debt portfolio and in addition to it, this small share is fully from the official sources which means it is less adapted to the changes in International financial markets. Due to reforms in interest rate policy, only around 0.4 per cent of internal debt is at floating rate and the remaining is at fixed interest rates providing stability to budget without any effect on interest payments (Status paper on Govt. debt, 2016) but this doesn't mean that it would not be a cause of concern. High inflation (because of printing of currency) could be as costly as external default.

The Fiscal Responsibility and Budget Management (FRBM) Act was enacted in 2003 to put a limit on rising government borrowings and deficits. The Government has succeeded fairly well in curtailing revenue, fiscal and primary deficits and liabilities. India's fiscal deficit reduced from 4.34 per cent in 
2003-04 to 3.5 per cent in 2016-17. The data in Table 1 reveals that India's total outstanding liabilities (as per cent of GDP) reached at its peak as a consequence of increasing salaries, pensions and interest liabilities in 2003 and after that the burden started falling because of the fiscal consolidation path chosen by the Government. But it has also shown upward movement in 2011-12 and 2015-16. In this respect, India stands as one of the highest indebted nation among the emerging economies.

Table 1: Government outstanding liabilities (as per cent of GDP)

\begin{tabular}{|c|c|c|c|c|c|}
\hline む્خ & 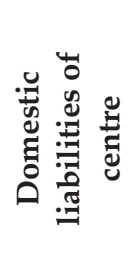 & 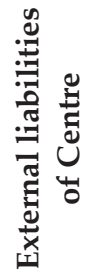 & 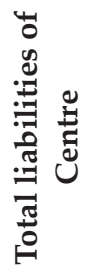 & 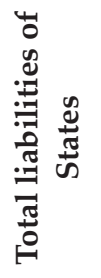 & 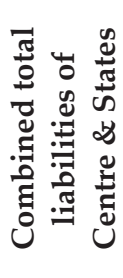 \\
\hline 2000-01 & 50.64 & 8.73 & 59.36 & 27.29 & 73.67 \\
\hline 2001-02 & 54.96 & 8.47 & 63.44 & 29.32 & 78.79 \\
\hline 2002-03 & 59.12 & 7.73 & 66.85 & 31.01 & 82.86 \\
\hline 2003-04 & 59.50 & 6.48 & 65.98 & 31.79 & 83.23 \\
\hline 2004-05 & 59.64 & 5.90 & 65.53 & 31.28 & 82.13 \\
\hline 2005-06 & 58.64 & 5.25 & 63.9 & 31.08 & 79.07 \\
\hline 2006-07 & 56.72 & 4.68 & 61.40 & 28.91 & 74.66 \\
\hline 2007-08 & 54.65 & 4.21 & 58.86 & 26.63 & 71.44 \\
\hline 2008-09 & 53.93 & 4.69 & 58.62 & 26.11 & 72.21 \\
\hline 2009-10 & 52.42 & 3.85 & 56.27 & 25.45 & 70.60 \\
\hline 2010-11 & 48.58 & 3.58 & 52.16 & 23.50 & 65.60 \\
\hline 2011-12 & 49.76 & 3.70 & 53.46 & 22.82 & 67.36 \\
\hline $2012-13$ & 49.21 & 3.34 & 52.55 & 22.23 & 66.65 \\
\hline 2013-14 & 48.83 & 3.33 & 52.16 & 22.00 & 67.06 \\
\hline 2014-15 & 48.57 & 2.94 & 51.51 & 21.73 & 66.70 \\
\hline 2015-16 & 48.91 & 2.97 & 51.88 & 23.21 & 68.61 \\
\hline 2016-17 & 47.52 & 2.78 & 50.30 & 23.91 & 68.56 \\
\hline
\end{tabular}

Source: RBI-Handbook of Statistics on Indian Economy 2017.

Since 2000-01, the picture is such that the domestic and external liabilities (as per cent of GDP) of the centre government have been falling since 2003 (except for two financial years) by following prudent fiscal path. The liabilities of states have reduced from 31.79 per cent in 2003-04 to 21.73 per cent in 2014-15 by following the rules of FRBM Act, 2003. Again, it has again embarked to spike after 2015 to 23.91 per cent in 2016-17 showing the vulnerable condition of the fiscal health of states because of increasing committed expenditure of state governments. The Combined liabilities of centre and state government has moved up conspicuously from 73.7 per cent in 2000-01to 83.3 per cent in 2003-04 after that it mitigated in later years and stood at 68.6 per cent in 2016-17 (Table $1)$. To review the results of implementation of FRBM Act, 2003, the Fiscal Responsibility Budget Management review committee headed by NK Singh was set up by the Government in May 2016 to review the results of implementation of FRBM Act, 2003. The committee submitted its report in 2017 and has recommended that the combined debt to GDP ratio of centre and states should be brought down to 60 per cent by 2023 (40 per cent of centre and 20 per cent of states) from the current ratio of 50.30 per cent of the centre and 23.91 of states which is much higher than the recommended ratio of 60 per cent. So,still there is a more room to elevate the performance by introducing more reforms related to debt management and subsidies because some studies also suggest prudent level of debt for the emerging economies at 60 per cent of GDP (Tapalova, 2013) and some rating agencies like S\&P ranked India at the lowest investment grade because of precarious fiscal situation of states and large general public debt.

\section{Indebtedness of Non Special category States (with particular reference to Punjab)}

The stress on state's fiscal health has manifested from persistent rise in revenue expenditure especially the non development component, stagnant growth in state's own tax revenue and sliding non-tax revenues. Increasing committed expenditure, low scope of rise in revenue receipts in the form of taxes and dilapidating State's public sector enterprises have left the state Governments to depend more on borrowings. Major portion of borrowings are used on revenue account rather than capital account which has retarded the economic growth of many non special category states.

Since, Punjab state of India also falls in the nonspecial category states, so a comparison of all non-special category states is made. The liabilities measured in terms of debt to GSDP ratio raised sharply from 2001 to 2004 \& were the highest among most of the states in 2004 but with the implementation of the rules of FRBM act in 2004, the ratio started declining gradually (Fig. 1). Out 


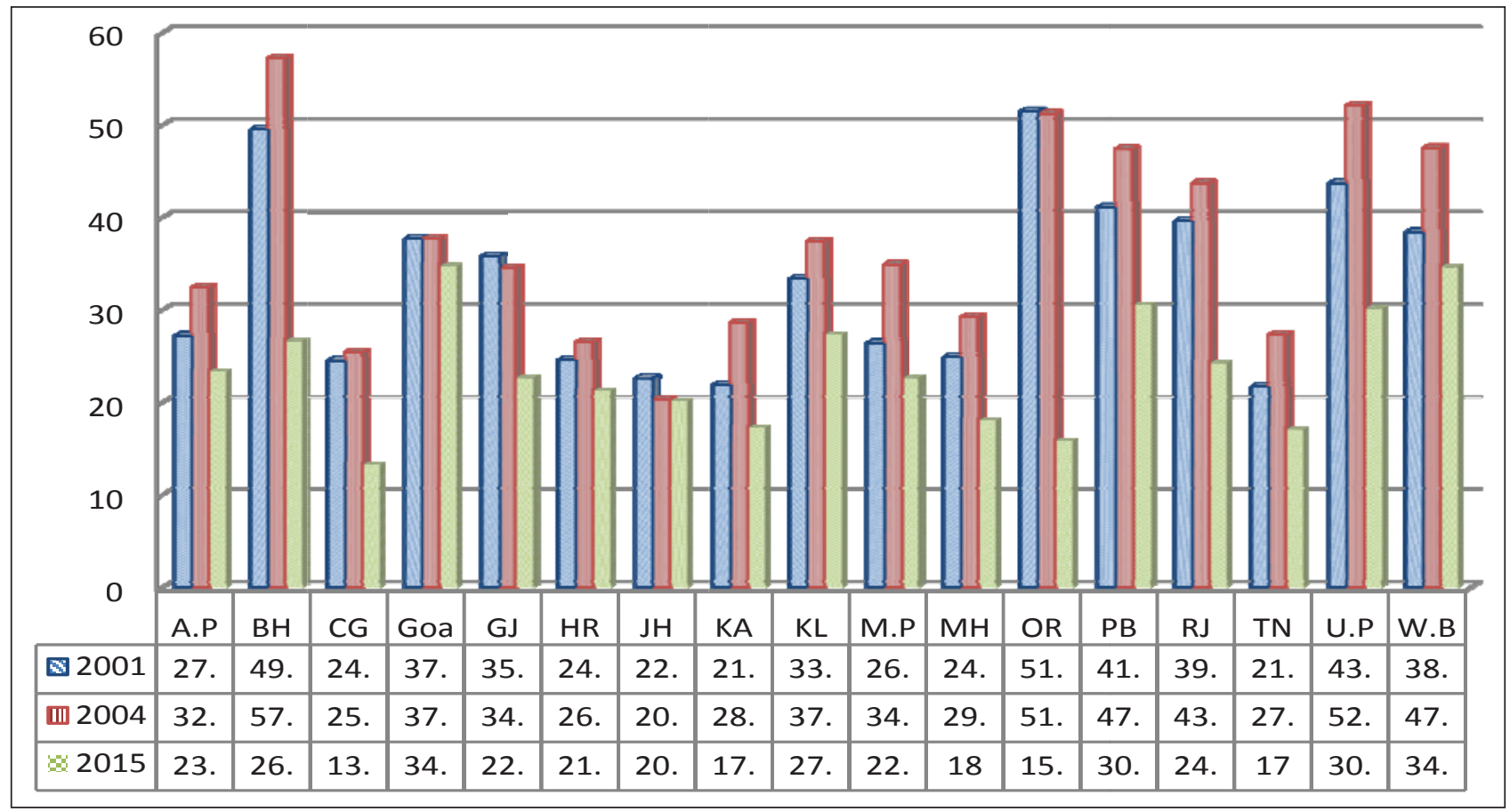

Fig. 1: Debt to GSDP ratio of non-special category States in India

Source: RBI-State Finances: A Study of Budget 2017.

of 17 non-special category states, debt-GSDP ratio had increased from 2001 to 2004, but all states have improved their position during 2004 to 2015. States with abysmal fiscal conditions having debt to GSDP ratio more than 30 per cent in 2015 are Goa (34.7), West Bengal (34.6), Punjab (30.5) and Uttar Pradesh (30.1).

Chhattisgarh (13.2), Odisha (15.8), Tamil Nadu (17), Karnataka (17.2) and Maharashtra (18) are comparatively in better positions with less than 20 per cent debt to GSDP ratio.

The maximum progress in reducing the dependence on borrowings has been shown by Odisha as the Debt to GSDP ratio of Odisha fell from 51.5 per cent in 2001 to 15.8 per cent in 2015 and its development expenditure has also increased from 12.7 per cent in 2001-02 to 14.5 per cent in 2014-15.

The states with lower outstanding liabilities and higher ratio of development expenditure as per cent of GSDP are Andhra Pradesh, Bihar and Madhya Pradesh. These states have also shown growth in the development expenditure from 2001 to 2015 (Table 2). Thus, these states are utilising funds for productive purposes which can pave the way to get better returns in future. Borrowings which are used for unproductive purposes cannot create enough funds to repay the debt and the burden of debt grows on.

Table 2: Development expenditure of Non-Special category States

\begin{tabular}{|c|c|c|c|c|}
\hline \multirow[b]{2}{*}{ 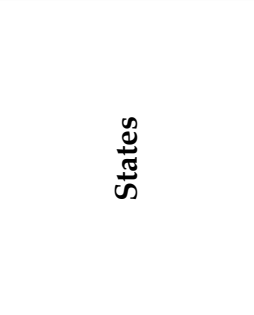 } & \multicolumn{2}{|c|}{ 2001-02 } & \multicolumn{2}{|c|}{ 2014-15 } \\
\hline & 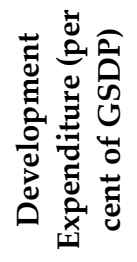 & 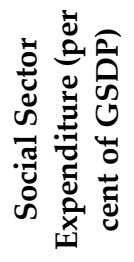 & 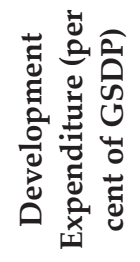 & 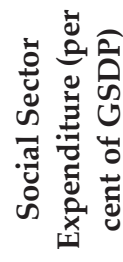 \\
\hline Andhra Pradesh & 12.7 & 6.9 & 18.7 & 10.4 \\
\hline Bihar & 13.7 & 10.0 & 16.8 & 11.3 \\
\hline Chhattisgarh & 12.1 & 8.3 & 15.3 & 10.1 \\
\hline Goa & 16.9 & 7.6 & 14.7 & 7.8 \\
\hline Gujrat & 14.0 & 7.3 & 8.9 & 5.3 \\
\hline Haryana & 10.4 & 5.6 & 8.3 & 5.0 \\
\hline Jharkhand & 15.3 & 10.6 & 12.5 & 8.2 \\
\hline Karnataka & 12.7 & 6.8 & 9.6 & 5.6 \\
\hline Kerala & 8.6 & 6.3 & 7.4 & 5.4 \\
\hline Madhya Pradesh & 12.7 & 6.9 & 16.6 & 9.2 \\
\hline Maharashtra & 9.0 & 5.7 & 7.5 & 4.9 \\
\hline Odisha & 12.7 & 8.8 & 14.5 & 9.1 \\
\hline Punjab & 8.8 & 4.7 & 7.1 & 4.2 \\
\hline Rajasthan & 11.7 & 8.4 & 13.5 & 9 \\
\hline
\end{tabular}




\begin{tabular}{ccccc} 
Tamil Nadu & 9.4 & 6.2 & 9.0 & 5.7 \\
Uttar Pradesh & 9.8 & 6.5 & 14.1 & 8.3 \\
West Bengal & 9.5 & 6.1 & 8.8 & 7.2 \\
\hline
\end{tabular}

Source: State Finances- A study of Budget (2004 and 2017).

Though these four states (Goa, West Bengal, Punjab and Maharashtra) have high levels of debt but end use of the debt is consequential rather than the level of debt. Punjab and West Bengal with the highest debt to GSDP ratios are spending very little amount on the development of the state. As compared to other non-special category states, both of these states have contributed less amount of GSDP on development expenditure in the year 2014-15 and the borrowings are used for paying interest payments and debt servicing. Interest payment holds maximum proportion of their revenue expenditure. Development expenditure as per cent of GSDP for Punjab has even dropped down from 8.8 per cent in 2001-02 to 7.1 per cent in 2014-15. Whereas Goa and Uttar Pradesh are disbursing more on the Developmental and social services relative to the other states with high outstanding liabilities. U.P.'s development expenditure as per cent of GSDP has mount upward to 14.1 per cent in 2014-15 from 9.8 per cent in 2001-02. Punjab performed poorly during last one and half decade in social sector expenditure with lowest SSE to GSDP ratio of 4.2 per cent among non special category states followed by Maharashtra as it had the second lowest share in social sector expenditure. While contrary to it, Chhattisgarh with the lowest debt to GSDP ratio is spending relatively more on development and social sector (Table 2) and its ratio of interest payment as per cent of GSDP is also low among the other states and it has decreased from 2.4 per cent in 2001-02 to 0.7 per cent in 2014-15 which shows that the state has been improving while otherwise economically better positioned states are more vulnerable to debt trap (Table 3).

The states which have shown improvement from the year 2001-02 to 2014-15 by spending more on development are Andhra Pradesh, Bihar, Chhattisgarh, Madhya Pradesh, Odisha, Rajasthan and Uttar Pradesh whereas states like Punjab, West Bengal, Gujrat, Jharkhand, Karnataka and Haryana have shown declining trend with this respect.
Table 3: Interest Payments of Non-Special category States

\begin{tabular}{ccc}
\hline \multirow{2}{*}{ States } & \multicolumn{2}{c}{$\begin{array}{c}\text { Interest Payments } \\
\text { (as per cent of GSDP) }\end{array}$} \\
\cline { 2 - 3 } & $\mathbf{2 0 0 1 - 0 2}$ & $\mathbf{2 0 1 4 - 1 5}$ \\
\hline Andhra Pradesh & 2.9 & 1.9 \\
Bihar & 4.8 & 1.6 \\
Chhattisgarh & 2.4 & 0.7 \\
Goa & 3.6 & 2.5 \\
Gujrat & 3.4 & 1.7 \\
Haryana & 2.5 & 1.6 \\
Jharkhand & 2.2 & 1.3 \\
Karnataka & 2.4 & 1.0 \\
Kerala & 0.3 & 1.9 \\
Madhya Pradesh & 2.6 & 1.5 \\
Maharashtra & 2.4 & 1.3 \\
Odisha & 6.1 & 0.9 \\
Punjab & 4.0 & 2.4 \\
Rajasthan & 4.2 & 1.7 \\
Tamil Nadu & 2.4 & 1.3 \\
Uttar Pradesh & 4.3 & 1.8 \\
West Bengal & 4.1 & 2.7 \\
\hline
\end{tabular}

Source: State Finances-a study of Budget by RBI (2004 and 2017).

With rise in debt burden, interest payments augment. With rising outstanding liabilities, interest payments also tend to incline upward and viceversa. From the financial year 2001-02 to 2014-15, the debt to GSDP ratio and interest payment as per cent of GSDP has reduced for all non-special category states. The states with the highest and the lowest ratio of interest payments as per cent to GSDP were Odisha (6.1) and Kerala (0.3) respectively in 2001-02. An improvement in this respect has surely occurred during one and half decade as West Bengal had a highest ratio of interest payment in GSDP i.e. 2.7 per cent and Chhattisgarh had minimum share i.e. 0.7 per cent in the year 2014-15.

Since, it is the composition of expenditure that influences the fiscal performance and makes an impact on the extent of Government liabilities by influencing economic growth. Disbursement of borrowings on the capital formation of country will increase the growth rate and eventually lead to lower debt to GDP ratio (Das, 2016) but states like Punjab and West Bengal have been borrowing more to pay interest payments rather than spending on 
productive purpose to boost the economic growth. So, there are more chances of these states to fall into a debt trap.

\section{Is Punjab falling into a Debt trap?}

Debt trap is a situation in which government borrows to pay the interest payments and debt incurred before. It is an unsustainable fiscal situation in macroeconomic context where government is not using financial resources for productive purposes which can service debt and hence, debt to GDP ratio keeps on growing.

Punjab state is passing through a fiscal crunch and declining growth rate for the last two-three decades. From the starting of the twenty first century, the state's debt to GSDP ratio crossed 40 per cent. No doubt, the state has adopted Fiscal Responsibility and Budget Management Act in May 2003 to improve fiscal management by containing excessive unproductive expenditure and improving resources for funds but even then, due to some reasons state's expenditure commitments continued to be at very high levels.

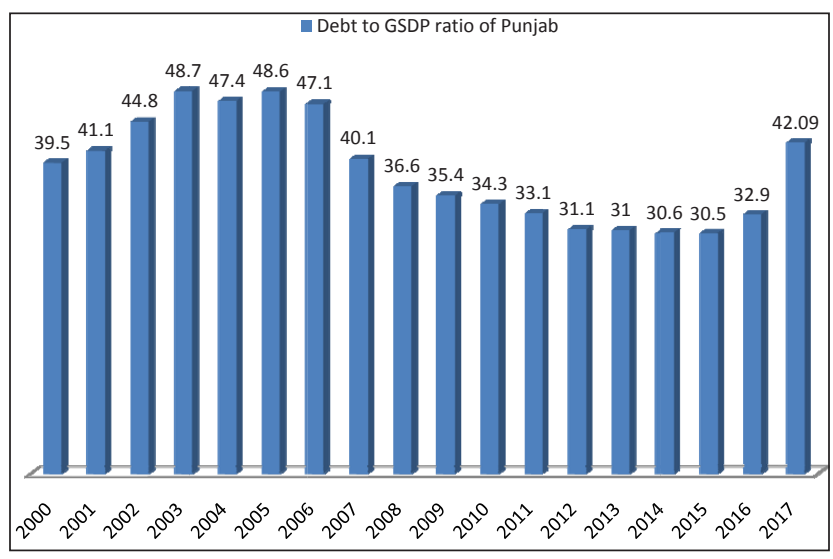

Fig. 2: Outstanding Liabilities of Government (as at the end of March)

Source: 1. RBI-State finances: A study of Budgets 2017, 2. Punjab Budget at Glance 2018-19.

After 2003, lack of sources to generate revenue and continuous dependence on borrowings to finance public expenditure had led to the situation of debt trap. Punjab is one of the heavily debt laden state whose amount of debt has raised from ₹ 30760 crore in 2001 to $₹ 112390$ crore in 2015. Fiscal deficit (as per cent of GSDP) of Punjab which was 6.2 per cent in 2001-02 has increased to 12.18 per cent in 2016-17 while on the other hand growth rate of the State that was 10.18 per cent in the financial year 2006-07 has declined to 4.9 per cent in 2014-15. Government's continuous dependence on borrowings is due to growing expenditure on interest payments and debt servicing.

Fig. 2 portrays that the debt to GSDP ratio has escalated till 2005 and the state experienced a very high ratio (i.e. 44 per cent to 48.6 per cent) during the first half of that decade. The situation occurred due to high revenue deficit as revenue receipts were not keeping pace with the growing revenue expenditure. But after 2005, the state has shown continuous decline in the outstanding liabilities as percentage to GSDP by keeping a check on expenditure side. Initially, the ratio declined at a faster rate but the pace slowed down after two years and the ratio has grown egregiously from 32.90 per cent in 2016 to 42.09 per cent in 2017. The state is not resorting to self liquidating borrowings which are not self liquidating. Hence, the burden of debt is growing in the state. So, for a long period, the State is facing huge financial crisis because of perpetual increase in the debt and inefficient utilisation of financial resources has retrograded the condition of State furthermore. Development expenditure of state as a percentage of GSDP has been decreasing and expenditure on capital outlay constitutes a very small portion of GSDP (shown in table 4). Social sector expenditure has declined to 4.2 per cent in 2014-15from 4.4 per cent in 2012-13. The state is neglectings pending on capital outlay, social sector etc. which can propel the growth rate. It is the rise in market borrowings through which surplus in capital account is created. The amount of capital receipts of Government was ₹ 9984.17 crore out of which market loans had a major contribution i.e. ₹ 7684.58 crore in 2014-15 and the state has been utilising the borrowed amount for revenue expenditure leaving lesser amount behind for capital expenditure which could improve the fiscal situation of the state. No doubt with the recent measures adopted by the state, revenue expenditure increased by relatively a less rate i.e. 21.84 per cent from previous year whereas revenue receipts increased by 28 per cent which resulted into the fall in revenue deficit from 7220.17 crore in 2015-16 to 6610.70 crore in 2016-17 which in itself is quite a high revenue deficit. Low share of tax revenue and falling share of central grants in the revenue receipts are the main reasons for such situation. 
On the other hand, the major portion of revenue expenditure is hold by interest payments, power subsidy, pension and retirement benefits that does not contribute to the growth of an economy. Rising revenue deficit will further increase the debt burden because the state will borrow more to cover up the revenue gap. Therefore, the debt deficit spiral exists in Punjab state.

Table 4: Expenditure outlay of Punjab

\begin{tabular}{|c|c|c|c|c|}
\hline ฮ્ర & 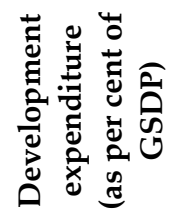 & 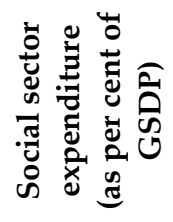 & 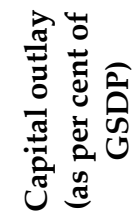 & 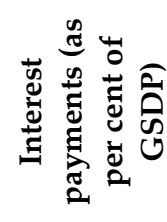 \\
\hline 2001-02 & 8.8 & 4.7 & 1.2 & 4.0 \\
\hline 2012-13 & 7.8 & 4.4 & 0.7 & 2.4 \\
\hline 2014-15 & 7.1 & 4.2 & 0.8 & 2.4 \\
\hline
\end{tabular}

Source: 1. RBI-State Finances: A study of Budget 2004 and 2017 2. RBI handbook of statistics on Indian states 2017.

The amount of interest payments is high and has been growing at alarming rate. The interest burden in the state is quite higher as compared to other states. It has been increased from ₹ 3178.05 crore in the financial year 2001-02 to ₹ 11641.76 crore. The growth rate of interest payments in 2016-17 over the previous year is 19.01 per cent in 2016-17 and if Government continues borrowing more for the disbursement of interest payments and debt servicing, then it will eventually fall into a debt trap.

High committed expenditure and paucity of financial resources can raise uncertainties in the future. Power subsidy given by the Government accounted for ₹ 2504.86 crore in 2014-15 has increased to $₹ 5600.70$ crore in 2016-17 and the revised estimate figure for 2017-18 stood at ₹ 10255 crore. Punjab has been providing power subsidy to farmers and schedule castes which is already a huge burden and instead of curtailing the amount or number of beneficiaries of subsidy, the state has now decided to give power subsidy of ₹ 748 crore to the industry for the year 2017-18. Besides it, the Government has announced ₹ 167.39 crore in 2017 and ₹ 4250 crore in the budget of 2018-19 for farm loan waivers. Since the fiscal position of Punjab is deteriorating day by day, the increasing amount of loans and subsidies would be unpropitious for the development of the State and lead to the further slippage of fiscal indicators. So, the amount to meet these needs should be generated by exploring new sources of finance.

According to the recommendations given by Fourteenth Finance Commission, fiscal deficit should not be more than 3 per cent of GSDP but flexibility of 0.25 per cent was given to the states with debt to GSDP ratio less than or equal to 25 per cent and the state has failed to achieve targets except in the year 2013-14, fiscal deficit has been pegged at more than 3 per cent of GSDP with debt to GSDP ratio more than 25 per cent. The situation became worse in 2016-17 when fiscal deficit was estimated as 12.18 per cent of GSDP because of increasing expenditure on revenue account and low tax and non-tax receipts. Under Fiscal Responsibility and Budget Management Act 2003, States were directed to eliminate revenue deficit by 2014-15 and have surplus on revenue account but again the Punjab state remained unsuccessful in achieving this target.

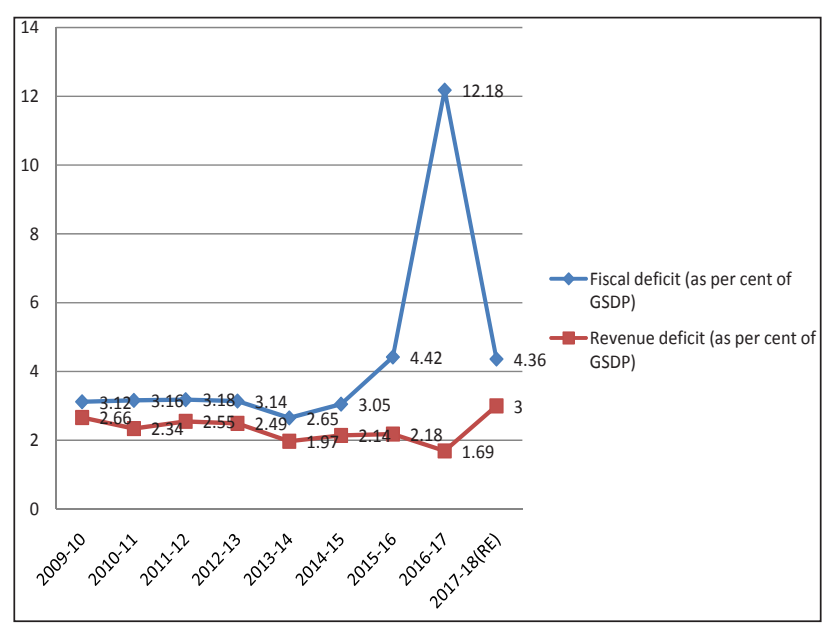

Fig. 3: Deficit indicators as per cent of GSDP in Punjab

Source: 1. Statistical Abstract Punjab 2016 2. Punjab Budget 2018-19 at glance.

Fiscal deficit of the state has remained close to 3 per cent of GSDP till the year 2014-15 after that it has risen sharply to 12.18 per cent in 2016-17. Revenue Deficit was estimated as more than 2 per cent of GSDP in the initial years of this decade and after that it declined to 1.69 per cent in the year 2016-17 but again a higher value is projected in the revised estimates for 2017-18 i.e. 3 per cent. Fiscal deficit and Revenue deficit are estimated as 3.81 per cent and 2.42 per cent respectively in the budget 2018-19. Hence, the deficit indicators reveal a grim picture of the state of Punjab. 
Total outstanding liabilities of the Punjab state were ₹ 182525.73 crore in $2016-17$ and are expected to rise ₹ 211522.68 crore in the year 2018-19. Punjab is facing huge fiscal crisis with rising revenue and fiscal deficit and it will adversely affect the growth and development of the economy. Debt receipts hold a major proportion of capital receipts than non-debt receipts. Capital receipts received by Government in 2016-17 were ₹ 83808.46 crore, out of which debt receipts were ₹ 8362.12 crore. High gap on revenue account will further lead to increase in fiscal deficit so the state should either curtail the amount of non-development expenditure like expenses on cars and petrol of ministers and officials and interest payment instead of borrowing or find new areas of resources and use the financial resources in more efficient manner or utilise the borrowings for more productive purposes which will relieve the state from the situation of debt trap. Government should have to spend more amount on the irrigation facilities (for the upliftment of the agriculture sector as Punjab being agriculture dominant economy) rather than spending on populist policies. Government can reduce the dependency on borrowings by paying more attention to State's public sector enterprises. State should prepare a fiscal consolidation path to reduce deficits and accumulation of debt for the upcoming years. Given the current scenario, the state government have to be more diligent while handling the financial resources.

\section{CONCLUSION}

India has been relying for long on public borrowings to meet its ever growing budgetary expenses specifically the revenue deficit. The domestic liabilities of the centre government as per cent of GDP has been rising since independence and reached closer to 60 per cent in 2004-05 but there after, these have started declining. However, external liabilities constitute a very small proportion of GDP. The government has undertaken many reforms like implementation of FRBM Act for the debt sustainability and long run macroeconomic stability but it could achieve the desired results for longer period as the combined ratio for centre and states started decreasing after the implementation of FRBM Act, but it further started rising in the recent years and has been estimated as 68.56 per cent. A comparative analysis of non special category states have been made which shows that West Bengal and Punjab have been facing financial crisis with high debt to GSDP ratio and low ratio of development expenditure to GSDP along with high rates of interest payment since one and half decade. On the other hand, states like Odisha, Chhattisgarh, Andhra Pradesh, Madhya Pradesh and Bihar are comparatively better in this respect. Punjab state had been able to combat the rising debt to GSDP ratio till 2015 from the period of adoption of FRBM Act. The public indebtedness is again rising which would further deteriorate the financial health of the state. Interest payments are rising at faster rate whereas development expenditure of the state is declining. So, the state needs to be more cautious otherwise they will eventually fall into a debt trap.

\section{REFRENCES}

Bilan, I. 2016. Overview of main theories on the economic effect on public indebtedness. EIRP proceedings, 11(1): 356-362.

Cottarelli, C. and Schaechter A. 2010. Long Term Trends in Public Finance in the G-7 Economies. IMF Staff Position Note. Available from:https://www.imf.org/en/ Publications/IMF-Staff-Position-Notes/Issues/2016/12/31/ Long-Term-Trends-in-Public-Finances-in-the-G-7Economies-24156.

Das, Panchanan. 2016. Debt Dynamics, Fiscal Deficit and Stability in governmental borrowings in India: A dynamic panel analysis. ADB working paper series. Available from: https://www.adb.org/publications/debt-dynamicsfiscal-deficit-and-stability-government-borrowing-indiadynamic-panel.

Department of Finance, Government of Punjab. Budget at a Glance, 2018-19.

Government of Punjab. Annual Financial Statement, 2017-18.

Government of Punjab. Statistical Abstract of Punjab, 2016.

International Debt Statistics. World Bank Group Report, 2017.

Joumard, I., Hoeller, P., Fournier, J. and Morgavi, H. 2017. Public debt in India: Moving towards a prudent level? OECD Economics Department Working Papers. Available from: http://dx.doi.org/10.1787/853c014a-en.

RBI. Handbook of Statistics on Indian Economy, 2017.

RBI. State Finances- A Study of Budget, 2004 \& 2017.

Ministry of Finance. Status Paper on Government Debt, 2016.

Tapalova, Petia and Nyberg, Dan. 2010. What Level of Public Debt Could India Target? IMF Working Paper. Available from: https://www.imf.org/en/Publications/ WP/Issues/2016/12/31/What-Level-of-Public-Debt-CouldIndia-Target-23511.

Tsoulfidis L. 2207. Classical Economists and Public Debt. RISEC, 54(1): 1-12. 